\title{
An investigation of apology strategies employed by Iranian EFL learners
}

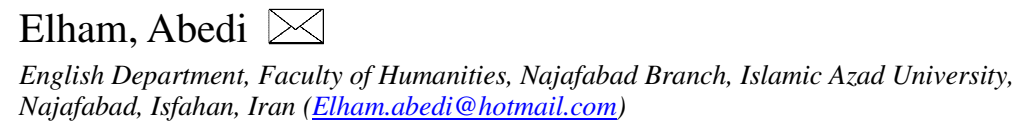

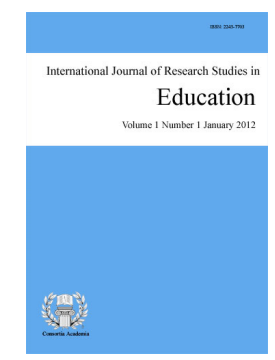

ISSN: 2243-7703 Online ISSN: 2243-7711

OPEN ACCESS

\section{Abstract}

A number of studies on apology strategies have investigated apologies cross-culturally. Rarely have apology strategies been scrutinized in Iranian context of EFL learning; nor have the respondents' gender that trigger such apologies been taken into account. This study was aimed to compare Iranian male and female EFL learners in terms of apology strategies. The participants were 50 Iranian EFL learners: (25 male, 25 female) both graduate and undergraduate students studying at Islamic Azad University, Najafabad branch. Discourse completion tests (DCT) were used in this study. In addition, Cohen and Olshtain's (1981) model was used for the classification of the different types of apology strategies used by EFL learners. It was found that the apology strategies of the first class, namely illocutionary force indicating devices (IFIDs), were the most commonly used strategies by Iranian EFL learners. Indeed, $67.48 \%$ of the entire number of the strategies used by EFL learners belonged to this category. Around $15.14 \%$ of the strategies are offer for repair by Iranian EFL learners, while the remaining strategies were scarcely used by Iranian EFL learners. In terms of gender, the results of a chi-square test showed that there was no statistically significant difference between male and female EFL learners with regard to their use of apology strategies: $\chi(10)=$ $2.69, p=.98$.

Keywords: speech act theory; speech act of apology; apology strategies; Iranian EFL learners; gender 


\section{An investigation of apology strategies employed by Iranian EFL learners}

\section{Introduction}

Pragmatics is the manner in which language is used in a specific situation by people; it studies the kind of words that they use to get their messages across. The hindrances that interlocutors may face are also discussed in pragmatics. Furthermore, the interaction between context and meaning are also explained in pragmatics. Briefly speaking, pragmatics focuses on what speakers mean, which is the illocutionary force of the utterance. Pragmatics investigates the rules that control the use of language in a specific context.

Language can be used to do some actions, which are called speech acts. Speech acts are in fact the phrases and words used to perform functions such as requesting, refusing, complimenting, greeting, thanking, and apologizing. Austin (1962) states that speech acts are functions which are done by words like apology and invitation. While, Crystal (2011) believes that speech acts can be done using different constituents of language including phrases, words or sentences. More important is that language learners must know the right forms of words. In addition, it is needed for them to know the why, when and how to use appropriate words. In addition, speech acts are carried out in daily interactions. The knowledge of the language along with proper use of the language in a culture is needed to be known by the speakers to prevent any problems in communication (Cohen \& Olshtain, 1981).

One of the common speech acts is the speech act of apology. As this study elaborates on the speech act of apology, this speech act will be discussed in the following section. Jebahi (2011) believes that through speech act of apology, it is tried to make up an offense committed by an offender; this is done to keep the balance between interlocutors. It is always observed that speech acts and their concepts differ across cultures. The way speakers from different languages and from different cultures respond to different speech acts are seemingly different from each other. As a case in this point as Rizk (2003) states, one can refer to the way English speaking people answer to compliments. In comparison with Persian speaking people who are expected to show humbleness in facing compliments, English native speakers may accept compliments without showing modesty. To give an example, an English native speaker may respond a compliment like 'Your performance was outstanding on the scene' with a simple word or phrase like 'thanks', that is without saying any other thing about the significance of the compliment as Wouk (2006) believes. However, within a similar situation, Iranian native Persian speakers may respond to the compliment with expressions like 'You're welcome' or 'That's very kind of you'.

A great number of such situations may happen within society regarding other speech acts like apology. In Iranian EFL learning context, however, the focus is mainly on learning about language rather than learning how to use language. Besides the grammar and lexis instruction in language classes, language learners should be well aware of how to use language in different contexts and situation. On the other hand, using the speech acts occur in society; therefore, it may differ across genders. However, the literature does not show much research in this area among Iranian Persian speakers. Thus the present study intended to investigate the speech act of apology among male and female Iranian EFL learners. The following research questions were posed to be answered in this research:

$>\quad$ RQ1: What types of apology strategies are usually employed by Iranian EFL learners?

$>\quad$ RQ2: How does gender affect the use of apology strategies among Iranian EFL learners?

\section{Literature Review}

From among some studies which have investigated the speech act of apology so far, some are discussed about in this section. One of such studies is the study by Banikalef, Maros, Aladdin and Al-natour (2015) who in 
a recent study studied apology studies within the Jordanian context. They gathered the data from a corpus of 1100 naturally occurring apology events through an ethnographic observation. Semi-structured interview was also used to investigate the effect of factors such as social status, social distance, and severity of offence on the kind of apology strategies. Convenient sampling was used to choose the participants. Olshtain and Cohen (1983) model was used to classify different types of apology strategies. The results showed that acknowledging responsibility was the most more frequently used than other apology strategies in Jordanian Arabic. In addition, acknowledging responsibility and swearing by God's name were found to be the most frequent combination of apology strategies in this Jordanian language. Non-apology strategies were also used with a high percentage. Furthermore, social status was found to be a stronger predictor of apology strategy compared with the severity of the offence or the social distance.

In line with the previous study, Marzuki (2013) also investigated pragma-linguistic conventions employed in apologies in short message system (SMS). The population included twenty six Malay native speakers. The data gathering instrument, like the present study was a Written Discourse Completion Tasks (WDCT) which required the respondents to respond to the situations through SMS. The situations were classified into two levels of offence and the participants were supposed to apologize through sending their apologies in SMS. The models used by Supyan (2006) and Crystal (2008) were used to categorize various apology strategies. Significant differences were observed in three situations when Malay Native Speakers (Malay NS) expressed their apologies in their second language (English) compared with the time when they used their first language to apologize through SMS. In addition, level of offence (slight offence compared with severe offence) led to significant differences. From this study it can be understood that the first language can lead to differences in conducting the apology strategies.

In another study, Tehrani, Rezaei, Dezhara, and Kafrani (2012) investigated the Iranian EFL learners in terms of various primary and secondary strategies used in different situations. In addition, they studied the effect of gender on different strategies. A questionnaire was developed by them based on Sugimoto (1997). Expression of regret was employed more than other strategies. Furthermore, female participants made use of these strategy more than male participants. Male participants used accounts, compensation reparation and negative assessment of responsibility. On the other hand, females used compensation, showing lack of intent to do harm, accounts, reparation more than other strategies. Evidently some gender differences are found from their study.

Similarly, Farashaiyan and Amirkhiz (2011) compared Iranian EFL learners and Malaysian ESL students in their using of the apology strategies. A discourse completion test (DCT) was used to collect the needed data. This study was conducted among 15 Iranian and 15 Malaysian students. It was found that Iranian and Malaysian EFL learners used some different and some similar apology strategies. However, from among the seventeen apology strategies Iranian EFL learners used fifteen strategies; however Malaysian EFL learners used eleven strategies. In another study, Parsa (2012) investigated apology and non-apology strategies among native Persian-speaking EFL students' according to Cohen and Olshtain's (1981) framework. The purpose of that study was to display dissimilarities which may be associated to the learners' gender, their mother tongue, and their culture. Different frequencies of apology and non-apology strategies were found to be used by Iranian male and female respondents used different percentages of apology and non-apology strategies. No statistically significant difference was observed among male and female learners considering the number and type of strategies used.

Similarly banikalef et al. (2015) and Al-Adaileh (2007) compared apology strategies in British English and Jordanian Arabic. His focus was mainly on politeness in Jordanian culture compared with British culture. Brown and Levinson's $(1987,1978)$ model of politeness was employed. In the model, two main constituents of face, namely, negative face and positive face were distinguished from each other. Open-ended questionnaire which was adopted from Cohen (1981), Olshtain (1983), Blum-Kulka and Olshtain (1984) and Reiter (2000), and interviews were used to gather data. Some situations of the questionnaire were slightly changed. It was found that British respondents used illocutionary force indicating devices (IFIDs) more than Jordanian respondents. Furthermore, all of the participants with two language backgrounds tended to use the expression of regret 
subcategory. Twelve situations were used in the questionnaire. The situations of the questionnaire included situations which were socially different and were similar to everyday events. The questionnaire was then translated into Arabic language.

It was found that the use of the sub-strategy like 'I am afraid + sentences' was employed only by British respondents. Then he concluded that this strategy is language-specific, which means that each language has its own expressions to realize its IFIDs. He then claimed that, the most frequent IFID expressions in the responses of Jordanian Arabic are as the following: asif, muta'a ssif, asef (sorry), verbs: atta'a ssaf (sorry), a 'tather (apologize), samehni (forgive me), and nouns: 'afwan (pardon), alma'thirah, and al'uther (apology). Finally, he concluded that apology is greatly under the influence of social parameters.

Also, Bataineh and Bataineh (2006) used a DCT to investigate apology strategies among Jordanian undergraduate EFL learners. They found some similarities between males and females in apology strategies; however, the participants used the apology strategies differently with a significant difference. Furthermore, Bataineh and Bataineh (2006), studied the EFL learners' apology with the use of a 10 item survey. In this study, it was shown that some similar strategies were used by male and female learners. However, the orders of using them were different. Their study also noted that male and female respondents used similar strategies of apologies, such as statement of remorse, accounts, compensation, promise not to repeat offense, and reparation. Furthermore, non-apology strategies such as blaming the victim and brushing off the incident as unimportant are seen as tactics used in evading the blame or misdirecting the blame toward others. Lastly, their study suggests that gender difference exist in the form of male respondents trying to direct the responsibility on the sufferer, while the females tend not to discuss the violation.

Abu Amoud (2008) used the framework proposed by Cohen and Olshtain (1981) to investigate the non-apology and apology strategies of Palestinian learners. It was observed that the female learners used more apology strategies than male learners, which was due to their politeness and shyness. However, more non-apology strategies were employed by male learners which were due to the society of Palestine which is mostly male-predominated. Furthermore, it was observed that the women spoke more to attract the addressee's forgiveness, while the men tended to use fewer words. Furthermore, Bataineh and Bataineh (2008) investigated the differences in the patterns of apology among native speakers of American English and Jordanian Arabic considering both genders in both groups. Differences in the use of apology strategies were observed. Some explicit apology strategies were the point of difference. The results also showed that apologies may hinder Jordanian EFL learners.

Istifçi and Kampusü (2009) analyzed two different English proficiency levels to find the differences and similarities in the use of strategies of apology between them and also to know whether the participants employed their own native speaker norms of apology or not. The study was based on Cohen and Olshtain's (1981) framework and 5 native speakers, 20 intermediate students, and 20 advanced students were the participants of their study. He reported that there were some differences and similarities between the two groups of participants. There was some influence of their first language on the exploitation of apologies and also the norms of native speakers of Turkish to a large extent transferred into English by intermediate levels. Moreover, advanced level participants, unlike their intermediate counterparts, exploited more norms of native speakers.

In essence, as shown in the previous mentioned literature review, not many studies have been conducted among the Iranian EFL learners context. In addition, there are some problems among how Iranian EFL learners implement apology strategies. Accordingly, to ridge the existing gap, the primary objective of the current study is to find out the apology strategies employed by Iranian EFL learners. In addition, the study also seeks to investigate the various issues regarding on how gender affects the use of apology strategies among Iranian EFL learners. 


\section{Methodology}

\subsection{Participants}

For the purpose of answering the research questions, the participants of this study included 25 male and 25 female graduate and undergraduate Iranian EFL learners studying at Islamic Azad University, Najafabad Branch. The participants are Persian native speakers and they had not lived in other countries. Random sampling was used.

\subsection{Research instruments}

In order to gather the data a discourse completion test (DCT) was adopted from Blum-Kulka (1980). This DCT was also used by Al Ali (2012) in his thesis. The used DCT questionnaire included nine apology situations based on various social contexts to investigate different strategies in these situations. Various apology strategies were classified based on Cohen and Olshtain's (1981) model. The DCT was translated into Persian in order to prevent any misunderstanding. The DCT was also changed in some cases so as to match with Iranian culture. In order to test the validity of the questionnaire, it was checked by some experts. As most of the situations described in the used DCT were taken from Al Ali's (2012) master thesis. At the outset of the study this DCT was piloted among 15 Iranian EFL speakers. The purpose was to check if the scenarios depicted are suitable. The results showed that all of the participants were able to complete the task in the allocated time. Finally, the internal consistency measure, calculated through Cronbach's alpha, was found to be .85 , which indicated an acceptable degree of reliability.

Cohen and Olshtain's (1981) model was used for classification of different types of apology strategies used by EFL Persian native speakers. Cohen and Olshtain (1981) categorized apology strategies as follow:

3.2.1 An Illocutionary Force Indicating Device (IFID)

- An expression of regret, e.g. I'm sorry

- An offer of apology, e.g. I apologize.

- A request for forgiveness, e.g. excuse me/ forgive me/ pardon me.

3.2.2. Explanation or account, e.g. there was a heavy traffic.

3.2.3. Taking on responsibility:

- Explicit self-blame, e.g. it's my mistake.

- Lack of intent, e.g. I didn't do it on purpose.

- Expression of self-deficiency, e.g. I totally forgot it.

- Expression of embarrassment, e.g. I feel ashamed.

- Self-castigation, e.g. It was very stupid of me.

- Justify the hearer, e.g. you are right to be angry and disappointed now.

3.2.4. An offer of repair, e.g. I'll pay for the damage.

3.2.5. Promise of forbearance, e.g. it won't happen again.

\subsection{Data collection procedures}

This study was aimed to investigate different apology strategies used by Iranian EFL learners. The needed information was provided for the participants. The used DCT consisted of nine situations and one hour was allocated to completing the DCT. The gathered data through DCT were analyzed by SPSS. Firstly, the participants' responses were identified based on Cohen and Olshtain's (1981) model. The gathered data were analyzed by descriptive statistics like frequency and percentage, and inferential statistics. A chi-square test was used to compare the responses of the two groups.

\section{Results}

The first research question intended to investigate different types of apology strategies employed by Iranian EFL learners. The results of data gathering regarding the first research question are given below. 
According to the descriptive statistics presented in Table 1, the apology strategies of the first class, namely, IFIDs were the most commonly used strategies by Iranian EFL learners. Indeed, $67.48 \%$ of the whole number of the used strategies by EFL learners belonged to this category. About $15.14 \%$ of the strategies employed by Iranian EFL learners were offer of repair.

\section{Table 1}

Distribution of Apology Strategies Used by Male and Female Iranian EFL Learners

\begin{tabular}{|c|c|c|c|c|c|c|}
\hline Strategy & \multicolumn{2}{|c|}{ Frequency } & \multicolumn{2}{|c|}{ Percentage } & \multicolumn{2}{|c|}{ Total } \\
\hline (1) Illocutionary force indicating devices (IFIDs), & IEFLF & IEFL/M & IEFLF & IEFL/M & Frequency & Percentage \\
\hline a. An expression of regret. & 97 & 104 & 21.60 & 23.16 & 201 & 44.76 \\
\hline b. An offer of apology. & 23 & 14 & 5.12 & 3.11 & 37 & 8.23 \\
\hline c. A request for forgiveness. & 31 & 26 & 6.90 & 5.79 & 57 & 12.69 \\
\hline (2)Explanation or account: & 39 & 33 & 8.68 & 7.34 & 72 & 16.02 \\
\hline (3)Taking on responsibility: & --- & --- & --- & --- & --- & --- \\
\hline a. Explicit self-blame. & 0 & 0 & 0 & 0 & 0 & 0 \\
\hline b. Lack of intent. & 1 & 0 & .22 & 0 & 1 & .22 \\
\hline c. Expression of self-deficiency. & 0 & 0 & 0 & 0 & 0 & 0 \\
\hline d. Expression of embarrassment. & 3 & 1 & 66 & .22 & 4 & .88 \\
\hline e. Admission of facts but not responsibility. & 1 & 0 & .22 & 0 & 1 & .22 \\
\hline f. Justify hearer. & 1 & 3 & .22 & .66 & 4 & .88 \\
\hline $\begin{array}{l}\text { g. Refusal to acknowledge guilt: Denial of } \\
\text { responsibility, Blame the hearer, Pretend to be } \\
\text { offended. }\end{array}$ & 1 & 0 & .22 & 0 & 1 & 0 \\
\hline (4) Concern for the hearer. & 0 & 0 & 0 & 0 & 0 & 0 \\
\hline (5) Offer of repair. & 34 & 34 & 7.57 & 7.57 & 68 & 15.14 \\
\hline (6) Promise of forbearance. & 0 & 1 & 0 & .22 & 1 & .22 \\
\hline Total & 233 & 216 & 50.97 & 49.03 & 449 & 100 \\
\hline
\end{tabular}

Explanation or account was the next class of apology strategies which was used by Iranian EFL learners. In fact, $16.02 \%$ of Iranian EFL learners chose this item as a strategy to apologize in different situations. Approximately, $15.14 \%$ of the strategies were offer of repair. Surprisingly, in the case of other strategies, in less than one percent of the whole situations, the participants made use of these strategies. Even in two cases, namely explicit self-blame and expression of self-deficiency, the strategies were never used. In the case of lack of intent only one respondent in one situation claimed to use this strategy. In response to situation 8 promise of forbearance (e.g. I won't do it again.) was used in just one situation (.22\% of the whole situations). Expression of embarrassment and justify hearer were also used in $.88 \%$ of the situations.

The second research question sought to investigate the way gender affected the use of apology strategies among Iranian EFL learners. The results of data analysis in this regard are summarized below. Nine situations were devised for the participants to investigate their response to different situations. The obtained responses are presented based on each situation in the following section.

Situation 1: Imagine that you are teaching at a university. It's morning and the head of your department has held a meeting now with a number of professors along with you. You don't know the head of the department well. He was noting something that you unintentionally interrupt him. She says angrily: 'I wasn't done. Please don't interrupt me.' What would you say?

EFL male respondents applied IFIDs, namely, expression of regret more than others (25.5\%). As the next apology strategy, which was used roughly with the same proportion by male and female EFL learners, offering an apology was used by the respondents. Iranian male and female EFL learners made use of request for forgiveness in the same range (13.45\%). As the next apology strategy, Explanation or account was used by a percentage of $8.56 \%$. Female learners applied this strategy only in two cases, but male learners did not use this strategy. An example of this strategy was 'I had an important appointment'.

Situation 2: Imagine that you are a teacher at a school and you are at the manager's office in order to have him sign some papers. You don't talk to the secretary, she tells you that the 
An investigation of apology strategies employed by Iranian EFL learners

manager is not in, while putting the papers on secretary's desk, you spill the orange juice all over her skirt. She says: "Oh, my goodness!" What would you say?

Male EFL learners made use of expression of regret less than female EFL learners. Another strategy namely Offering an apology was also used just rarely. Request for forgiveness was also used by EFL learners; however, among EFL learners, males used this strategy more than females. Other strategies like explanation or account were used by female EFL learners more than others. Offer of repair was used by $13 \%$ by EFL learners who used this strategy. In situation 2, the interlocutors were roughly in the same social level.

Situation 3: Imagine that a student has planned to meet you for a paper revision for a conference. You are a university professor, and you do not know the student. Due to an urgent meeting you miss the appointment. The next day you see the student in your office. What would you say to her?

The first type of apology strategy, namely expression of regret, was used more than other strategies by EFL learners. However, female learners used this strategy more than males. On the other hand, EFL learners did not employ explicit self-blame at all. Female EFL learners used expression of embarrassment only in one case.

Situation 4: As a college student you were absent in two classes, and now you have forgot the medical statement as a reason. This was the first experience of your absence. Your professor, who is teaching you for the first time, is a nice person. You are going to discuss the case. You are in her office now. What would you say?

Offer of repair was employed by male and female Iranian EFL learners 5 times. Female Iranian EFL learners used offer of apology only in 9\%. Male Iranian EFL learners used this strategy only in $2 \%$ of situations. The strategy of explicit self-blame was used only by female Iranian EFL learners in 6 cases. Iranian male EFL learners used Request of forgiveness only in $2 \%$ of cases. Female Iranian EFL learners used this strategy in $3.2 \%$ of cases. An example is the phrase excuse me. As the last strategy used in response to this situation, promise of forbearance was used only by $2 \%$.

Situation 5: Imagine that you are a freshman and you are late. You hit another student's foot while running to class. You don't know this student. She says angrily "Hey, be careful!" What would you say?

Like the previous situations, the strategy of expression of regret was used more than other strategies. Male and female Iranian EFL learners used this strategy equally (26\% compared with $24 \%$ ). The strategy of Offer of apology was used only by $4 \%$ of Iranian EFL learners ( $2 \%$ by males and $2 \%$ by females).

Situation 6: You are a freshman in college dormitory. You are watching a movie in your room when the student living in next room, knocks and says: 'Would you mind turning down the TV? I have an exam tomorrow and I can't concentrate.' What would you say?

Like the previous strategies, in this situation, the respondents used the first type of apology strategies i.e. expression of regret more than other strategies. Among EFL learners, female respondents used expression of regret more than males. Similarly, request for forgiveness was used only once by a male EFL learner. Explanation or account was not used by the male participants at all.

Situation 7: You have two kids and you along with some friends are invited to your friend's house for the first time. All the children are playing in the house when your younger son breaks an expensive vase. Your friend's wife says "Oh, no, this was a gift from my sister." What would you say?

According to the scenario presented in situation 7, the strategy offering repair was more likely to occur due 
to the fact that sort of monetary damage has taken place and offering a repayment may be suitable. On the contrary to this premise, the data revealed that expression of regret, was again used more than other strategies. Female EFL participants chose this strategy more than males. Explanation or account was also used in a low frequency by EFL respondents, $2 \%$ by males and $2 \%$ by females.

Situation 8: You and your friends are studying in the. There are some other students in the library and they are studying as well. The librarian tells you to be quiet in an angry tone of voice. What would you say?

The strategy of expression of regret was used by male and female EFL learners equally. Offer of repair was also used by male and female EFL learners with roughly the same frequency.

Situation 9: Imagine that you have recently started a job, the other day you had a conflict with someone you didn't know, now you see he is your new boss. What would you say?

Male EFL learners used expression of regret more than female ones. To put the foregoing results on solid ground, chi-square test was used to see if there was a difference between male and female speakers regarding the use of apology strategies or not. The results of these statistical analyses are illustrated in Tables 2.

\section{Table 2}

The Results of Chi-Square Test Comparing Male and Female EFL Learners in Their Apology Strategies

\begin{tabular}{llll}
\hline & Value & $d f$ & Asymp. Sig. (2-sided) \\
\hline Pearson Chi-Square & 2.69 & 10 & .98 \\
Likelihood Ratio & 3.46 & 10 & .96 \\
Linear-by-Linear & .007 & 1 & .93 \\
Association & 100 & & \\
N of Valid cases & &
\end{tabular}

Based on the information presented in Table 2, $\chi(10)=2.69, p=.98$. Since the $p$ value was found to be greater than the significance level (i.e. .05), it could be understood that there was no statistically significant difference between male and female EFL learners with regard to their use of apology strategies.

\section{Discussion and Conclusion}

Thus, according to the results presented earlier, it can be concluded that from among apology strategies, illocutionary force indicating devices (IFIDs) were used more than other strategies. Explanation or account and Offer of repair were employed as the next two categories of apology strategies. In addition, it can be concluded that although some differences were observed between male and female EFL learners, it was seen that gender differences does play a significant role in employing apology strategies.

The first research question of the present study intended to investigate the apology strategies used by Iranian EFL learners. The results showed that the strategies included in the category of IFIDs were used more than other categories. Other types of apology strategies were used in a very low frequency. The reason for not using other categories like taking the responsibility may be due to the fact that Iranians are less likely to overtly accept responsibility for an offense. Additionally, from among the many sub-strategies associated with 'taking on responsibility', EFL learners used only a relatively small sub-set, particularly, 'expressing lack of intent'. In Persian, there is a considerable variety of routine formulae that can be utilized by the offender (apologizer) in apologizing. Approximately, all remedial exchanges in Persian involved an explicit expression of apology (or IFID), and the high application of this category by EFL learners of English can be attributed to this fact. According to Eslami-Rasekh (2005) in Persian, expressions of apology are formulaic; Persian speakers use them in fixed ways which show the socio-cultural norms in the Iranian society. Like other languages studied, e.g. Cohen and Olshtain (1981) and Vollmer and Olshtain (1989), in Persian, an expression of apology (or IFID) has 
An investigation of apology strategies employed by Iranian EFL learners

some subformulas, each of which has a performative verb, like an apology verb, like bækhshidæn ('to forgive'), Pozr khastæn ('to apologize'), motæ' æsef budæn ('to be sorry'), shærmænde budæn ('to be ashamed') and hælal kærdæn ('to forgive') (Eslami-Rasekh, 2005).

According to what was said earlier, the participants responded to nine situations. In the previous section, the results of the nine situations in terms of gender were discussed. As it was said, 'expression of regret' was used by male EFL students more than female EFL learners. This may be due to the fact that among Iranian people, usually ladies, tend not to apologize very much, specifically when their interlocutor is another woman. It was found that EFL male respondents applied expression of regret more than others, which may be due to the fact that in Iranian culture, against females, males are more humble, and therefore, they are more likely to express regret. In Iran people tend to stand on ceremony more than English native speakers, and due to this, it seems that they usually do not drop formalities and this leads to the fact that they do not directly embark on offering repair.

To wrap it up, the findings revealed that although males and females used some similar strategies, they applied them in different orders. In this sense, the results of this study are in line with the study by Abu Amoud (2008) who analyzed the apology and non-apology strategies of Palestinian students in Hebron University based on Cohen and Olshtain (1981)'s framework. Also results of this study are in line with those of Bataineh and Bataineh (2006) indicating that although males and females used some similar strategies, they applied them in various orders.

Also the results of the present study are in line with the study conducted by Al Ali (2012). However, in that study, the speech act of apology made by female Saudi native Arabic speakers and female Australian native English speakers were investigated. In the present study, however, EFL learners were examined in terms of their using of apology strategies. Power between the interlocutors and level of imposition were also investigated in $\mathrm{Al}$ Ali's (2012) study. Furthermore, the role of culture in influencing the ways in which language speakers carry out their apologies was also investigated in that study.

The results of the present study are of significance in a way that they can be useful for those language learners interested in increasing their knowledge of pragmatics in general and apology speech acts in particular. They develop a useful path for those researchers who are interested in studies of discourse pragmatics as well. EFL and ESL teachers and leaners can make use of the results of this study to raise their consciousness about their sociolinguistic and pragmatic awareness. The results can also help teachers while teaching pragmatic rules in the classroom. Another implication is the need for raising Iranian EFL learners' awareness and understanding of cultural differences between their native language culture and that of the target language since sociolinguistic variations are related to culture. The findings of the present study show the norms of native Iranian were often transferred into English when Iranian EFL learners produced an interlanguage apology.

In additions, in realizing the speech act of apology, EFL learners usually encounter problems; therefore, pedagogical implications can also be argued considering raising sociolinguistic and pragmatic awareness of EFL learners in order to provide a better picture of the socio-pragmatic aspects of speech acts of apology in English. Teachers also can take advantage of the outcomes of the present research to develop pragmatic teaching to EFL learners.

The present study showed the importance of socio-pragmatic knowledge; therefore, EFL teachers should know that to be fluent in English language involves not only linguistic knowledge but also sociocultural knowledge. Through comparison of the similarities and differences in apologies of L1 and L2 learners' linguistics and pragmatics awareness can be enhanced in EFL learning. Teaching pragmatic competence and apology strategies in the language classroom can be enhanced through application of the findings of the present research.

Another implication deals with EFL teaching materials. This is due to the fact that ELT materials try to present materials that reflect native English speakers' culture in real life situations. The ELT textbooks should 
present materials which are based on samples of authentic materials. Accordingly, material developers should not present only one semantic formula like "sorry", "I'm sorry" or "I'm very sorry." The opportunity should be provided for Iranian EFL learners to work on their communicative competence in the language classroom.

\section{References}

Abu Amoud, M. S. M. (2008). A study of apology strategies among Hebron University students (Unpublished masteral thesis). University of Malaya. Malaysia.

Al Adaileh, B. (2007). The speech act of apology: A linguistic exploration of politeness orientation in British and Jordanian Culture (Doctoral thesis). The University of Leeds.

Al Ali, S. A. S. (2012). A cross-cultural study of the speech act of apology by Saudi and Australian females (Unpublished masteral thesis). University of Melbourne, Australia.

Austin, J. L. (1962). How to do things with words. Oxford: Oxford University Press.

Banikalef, A., A., A., Maros, M., Aladdin, A., \& Al-natour, M. (2015). Apology strategies in Jordanian Arabic. GEMA Online Journal of Language Studies, 15(2), 83-99. http://dx.doi.org/10.17576/gema-2015-1502-06

Bataineh, R. F., \& Bataineh, R. F. (2006). Apology strategies of Jordanian EFL university students. Journal of Pragmatics, 38(11), 1901-1927. http://dx.doi.org/10.1016/j.pragma.2005.11.004

Bataineh, R. F., \& Bataineh, R. F. (2008). A cross-cultural comparison of apologies by native speakers of American English and Jordanian Arabic. Journal of Pragmatics, 40(4), 792-821. http://dx.doi.org/10.1016/j.pragma.2008.01.003

Blum-Kulka, S., \& Olshtain, E. (1984). Requests and apologies: A cross-cultural study of speech act realization patterns (CCSARP). Applied Linguistics, 5(3), 196-213. http://dx.doi.org/10.1093/applin/5.3.196

Brown, P., \& Levinson, S. (1978). Universals in language use: Politeness phenomena. In E.N. Goody (Ed.), Questions and politeness (pp. 56-289). Cambridge: Cambridge University Press.

Brown, P., \& Levinson, S. C. (1987). Politeness: Some universals in language usage. Cambridge University Press. NewYork.

Cohen, J. R. (1981). Advising clients to apologize. Southern California Law Review, 72, 1009-1026.

Cohen, A. D., \& Olshtain, E. (1981). Developing a measure of sociocultural competence: The case of apology. Language Learning, 31(1), 113-134. http://dx.doi.org/10.1111/j.1467-1770.1981.tb01375.x

Crystal, D. (2008). Texting. ELT Journal. 62(1), 77-83. http://dx.doi.org/10.1093/elt/ccm080

Crystal, D. (2011). Dictionary of linguistics and phonetics. Wiley.

Demeter, G. (2006). A pragmatic study of apology strategies in Romanian. Oklahoma State University, The USA.

Eslami-Rasekh, Z. (2005). Raising the pragmatic awareness of language learners. ELT Journal, 59(3), 199-208. http://dx.doi.org/10.1093/elt/cci039

Farashaiyan, A., \& Amirkhiz, S. (2011). A descriptive-comparative analysis of apology strategies: The case of Iranian EFL and Malaysian ESL University Students. English Language Teaching, 4(1), 224-236. http://dx.doi.org/10.5539/elt.v4n1p224

Istifçi, I., \& Kampusü, Y. (2009). The use of apologies by EFL learners. English Language Teaching, 2(3), 15-25. http://dx.doi.org/10.5539/elt.v2n3p15

Jebahi, K. (2011). Tunisian university students' choice of apology strategies in a discourse completion task. Journal of Pragmatics, 43(2), 648-662. http://dx.doi.org/10.1016/j.pragma.2010.09.008

Marzuki, E. (2013). Linguistic features in SMS apologies by Malay native speakers. GEMA Online Journal of Language Studies, 13(3), 179-192.

Olshtain, E. (1983). Apologies across languages. Cross-Cultural Pragmatics: Requests and Apologies, 15, 51-73.

Olshtain, E., \& Cohen, A. (1983). Apology: A speech act set. Sociolinguistics and Language Acquisition, 12, $18-35$.

Parsa, H. (2012). Apology strategies of Iranian ESL students (Unpublished masteral thesis). University of Malaya, Malaysia. 
An investigation of apology strategies employed by Iranian EFL learners

Reiter, R. M. (2000). Linguistic politeness in Britain and Uruguay: A contrastive study of requests and apologies. John Benjamins Publishing. http://dx.doi.org/10.1075/pbns.83

Rizk, S. (2003). Why say “NO!” when you refuse. Journal of the Faculty of Education, 3, 1-27.

Sugimoto, N. (1998). Norms of apology depicted in US American and Japanese literature on manners and etiquette. International Journal of Intercultural Relations, 22(3), 251-276. http://dx.doi.org/10.1016/S0147-1767(98)00007-8

Sugimoto, N. (1997). A Japan-US comparison of apology styles. Communication Research, 24(4), 349-369.

Supyan, H. (2006). The features in Malay SMS texts. In L.S. Chin \& T. K. Hua (Eds.), Composing meanings: Media text and language (pp. 61-73). Bangi: UKM.

Tehrani, M. D., Rezaei, O., Dezhara, S., \& Kafrani, R. S. (2012). Apology strategies of Iranian undergraduate students. English Language Teaching, 5(2), 93-109.

Vollmer, H. J., \& Olshtain, E. (1989). The language of apologies in German. Cross-Cultural Pragmatics: Requests and Apologies, 3, 197-218.

Wouk, F. (2006). The language of apologizing in Lombok, Indonesia. Journal of Pragmatics, 38(9), 1457-1486. http://dx.doi.org/10.1016/j.pragma.2005.09.011 
Elham, A. 